\title{
High Resolution Three-dimensional Space Charge Distribution Measurement System
}

\author{
Tomoya Maeda Student Member (Waseda University, maeda.tom@suou.waseda.jp) \\ Yoshimichi Ohki Member (Waseda University, yohki@waseda.jp) \\ Atsuhiro Nishikata Non-member (Tokyo Institute of Technology) \\ Takashi Maeno Member (National Institute of Information and Communications Technology)
}

Key words: charge distribution, pulsed electroacoustic method, three-dimensional space charge measurement, insulating material, solid insulation

The pulsed electroacoustic (PEA) method has already been widely used to measure the space charge distribution in solid dielectric materials. Since conventional PEA systems can measure the distributions only along the thickness direction, we developed a new system, called 3D-PEA, with a capability of doing three-dimensional measurements by applying a new acoustic lens to the conventional PEA system. As its external view is shown in Fig. 1, the whole measurement system consists of an aluminum upper electrode system, an aluminum lower electrode, the acoustic lens mounted on a sensor, an amplifier, and an $x-y$ stage. A water layer is used to transmit pressure waves from the lower electrode to the acoustic lens. In the 3D-PEA system, only the pressure waves generated at the focal area are detected by the sensor (PVDF, $8 \mathrm{~mm} \phi \times 9 \mu \mathrm{m}$ thick). Therefore, by controlling numerically the position of the sensor in the lateral direction using the $x-y$ stage, three dimensional space charge distributions are obtained. In this paper, we describe the design of the new lens and the resolution of this system.

Acoustic waves generated by charges upon the application of a pulsed electric field travel toward the sensor through the lower electrode, the water layer, and the acoustic lens. Due to the difference in the sound velocity between aluminum and water, the pressure waves generated at the same focal area but traveled through different paths are not able to reach the sensor in the same phase in the case of the previous system with the old lens I . This limits the lateral resolution of the previous system. Therefore, we adopt the new nonspherical acoustic lens II that was designed to accommodate to the detective system.

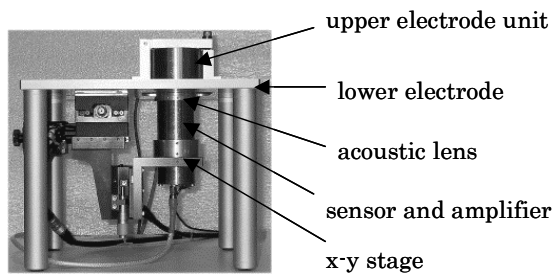

Fig. 1. External view of the 3D space charge distribution measurement system

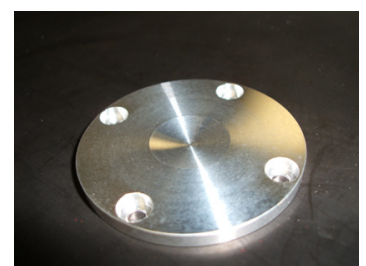

Fig. 2. The acoustic lens made by aluminum (lens II)
Figure 2 shows a picture of lens II . The upper surface of lens II, made of aluminum, was ground to a concave shape so that the path length from the focal point to the bottom of the lens II is always constant as long as it satisfies the refraction law of pressure waves at all the interfaces of different materials.

The resolution in the thickness direction was compared between the old and the new systems. Namely, a dc voltage, $10 \mathrm{kV}$, was applied to a PMMA board with a thickness of $0.5 \mathrm{~mm}$, and the charge distribution on the lower electrode surface was compared. The resolution in the thickness direction, defined by the full width at half maximum, becomes $16 \mu \mathrm{m}$ for the new system with lens II in comparison with $30 \mu \mathrm{m}$ for the old system.

Then, we measured space charge distribution in a PVC board with a surface charged region of $1 \mathrm{~mm}$ in width and $0.3 \mathrm{~mm}$ in thickness on the lower-electrode side. Figure 3(a) shows the cross-sectional charge distribution measured by the PEA system with lens II, while Fig. 3(b) compares the charge distributions on the lower electrode measured by the system with lens I and by the one with lens II. If the distance between the position at which the charge density is highest and the one at which the charge density becomes a half of the maximum is defined as the resolution in the lateral direction, it has been improved from 500 $\mu \mathrm{m}$ for lens I to $100 \mu \mathrm{m}$ for lens II.
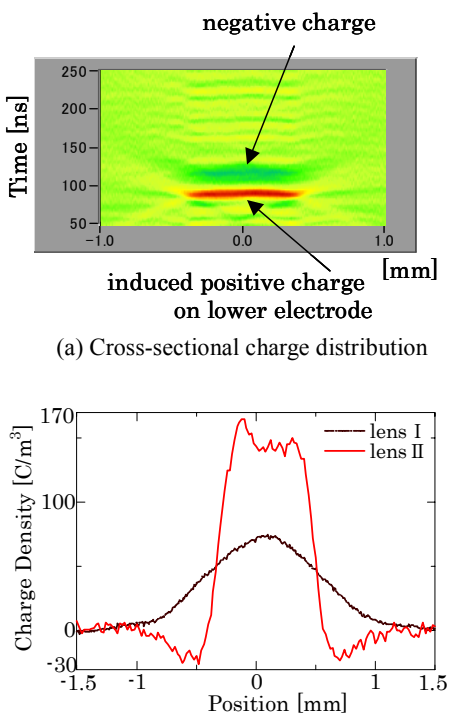

(b) Charge distribution on the lower electrode surface

Fig. 3. Charge distribution in PVC with a surface charged region on the lower-electrode side 


\title{
高分解能三次元空間電荷分布測定装置
}

$\begin{array}{llll}\text { 学生員 前田 } & \text { 知哉* } & \text { 正 員 大小 } & \text { 義路* } \\ \text { 非会員 西方 } & \text { 敦博** } & \text { 正 員 前野 } & \text { 恭*** }\end{array}$

\author{
High Resolution Three-dimensional Space Charge Distribution Measurement System \\ Tomoya Maeda*, Student Member, Yoshimichi Ohki*, Member \\ Atsuhiro Nishikata**, Non-member, Takashi Maeno***, Member
}

The pulsed electroacoustic (PEA) method has already been widely used to measure the space charge distribution in solid dielectric materials. Since conventional PEA systems can measure the distributions only along the thickness direction, we developed a new system with a capability of doing three-dimensional measurements. However, the system did not have a good lateral resolution. Therefore, in this research, we designed a new nonspherical acoustic lens. As a result, the resolution has been improved both in the thickness direction and the lateral direction.

キーワード : 電荷分布, パルス静電応力法, 三次元空間電荷測定, 絶縁材料, 固体絶縁

Keywords : charge distribution, pulsed electroacoustic method, three-dimensional space charge measurement, insulating material, solid insulation

\section{1. まえがき}

空間電荷測定法の一つにパルス静電応力法（PEA 法）が ある。本測定法は板状誘電体試料の厚さ方向空間電荷分布 を測定するものであるが，我々は音響レンズを併用して測 定することで，三次元空間電荷分布測定を可能にする装置 (3D-PEA 装置) の開発を行い(1)，既にプリント基板のイオ ンマイグレーションの評価などに使用している(2)。この装置 では，焦点領域で発生したのちにさまざまな方向へ伝搬し た圧力波が音響レンズで集められ圧電素子に伝えられ，信 号として検出される。このとき, さまざまな方向に進展し た全ての圧力波が同位相で圧電素子に到達することが必要 である。しかし，実際にはレンズの形状が装置の構造に適 していない球面となっていたことから，圧力波は同位相で

* 早稲田大学 電気・情報生命工学科

干169-8555 東京都新宿区大久保 3-4-1

Department of Electrical Engineering and Bioscience, Waseda University,

3-4-1 Ohkubo, Shinjuku-ku, Tokyo 169-8555

** 東京工業大学 教育工学開発センター

T152-8552 東京都目黒区大岡山 2-12-1

Center for Research and Development of Education

Technology, Tokyo Institute of Technology,

2-12-1 Ohokayama, Meguro-ku, Tokyo 152-8552

*** 情報通信研究機構 ライダーグループ

在184-8795 小金井市貫井北町 4-2-1

Lidar Group, National Institute of Information and

Communications Technology,

4-2-1 Nukuikitamachi, Koganei 184-8795
は圧電素子に到達せず, 電荷像は歪んでしまい, 面方向分 解能は $500 \mu \mathrm{m}$ 程度(1)であった。プリント基板では $100 \mu \mathrm{m}$ 程度の配線も用いられるため, この程度の分解能を目標と して非球面レンズを用いた新装置を開発した。本報告では, この新装置を紹介し, 装置の分解能を評価する。

\section{3D-PEA 装置とレンズの設計}

〈2·1〉3D-PEA 装置 3D-PEA 装置の外観を図 1 に, 概念図を図 2 に示す。これらの図に示されるように, 本装 置は, 高分解能 PEA 装置 ${ }^{(3)}$ の下部接地電極と圧電素子の間 に, 圧力波伝搬用の水とアルミニウムより成る超音波レン ズを付加したものである。電極部は, 直径 $8 \mathrm{~mm} \phi$ のアルミ

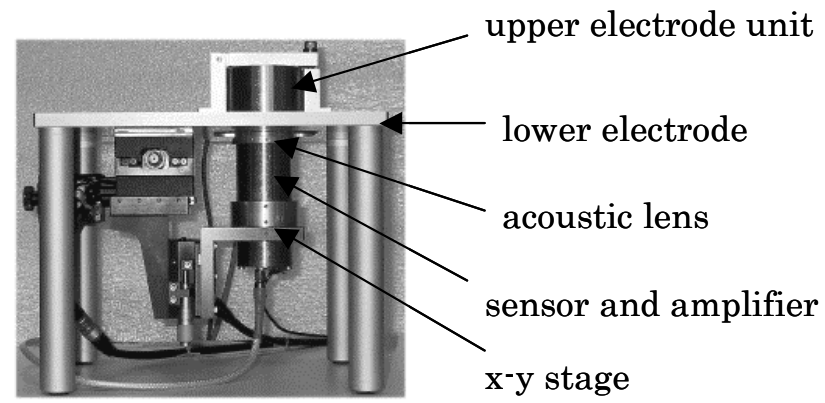

図 $13 \mathrm{D}-\mathrm{PEA}$ 装置の外観

Fig. 1. External view of the 3D space charge distribution measurement system. 


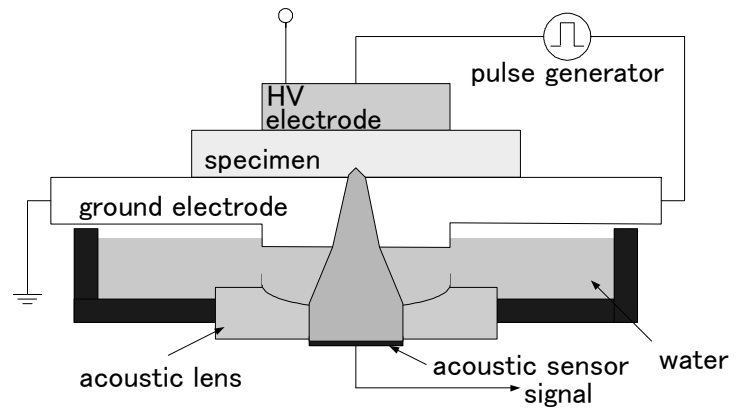

図 2 凹面の音響レンズを持った 3D-PEA 装置の 信号検出系概念図

Fig. 2. Schematic diagram of the $3-\mathrm{D}$ signal detecting system having a cylindrical acoustic lens with a concave surface.

ニウム円柱に半導電性ポリ塩化ビニル層を貼り付けた上部 電極と十分に広い厚さ $5 \mathrm{~mm}$ の平板状アルミニウム下部電 極より構成されている。さらに，信号検出用の圧電素子には 厚さ $9 \mu \mathrm{m}$ のポリふっ化ビニリデン (PVDF) を用いた。直 径が大きいほうが焦点を小さくできるため直径 $8 \mathrm{~mm}$ とし た。また, パルスジェネレータは, 繰り返し周波数 $2 \mathrm{kHz}$,

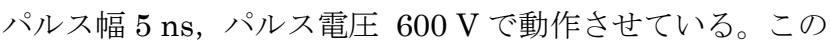
構成，およびパルス電圧やバイアス電圧の印加方法は，従 来の高分解能 PEA 装置(3) と全く同一である。

〈2·2〉レンズの設計本装置では, 試料中の全空間 電荷は, 高電圧パルス印加時に同時に圧力波を発生するが, 図 2 のようにレンズの焦点領域に存在している空間電荷よ りの圧力波のみが信号として検出されるため, 微小領域の 測定が可能となっている。すなわち，焦点領域以外からの 圧力波も圧電素子に到達するが，位相が揃わないために打 ち消しあう。また, 試料内の厚さ方向の空間電荷分布につ いては, 従来の PEA 法と同様に圧力波が圧電素子へ到達す る時間差より求める。その後, レンズと圧電素子からなる 信号検出部を, $x$ - $y$ ステージにより面方向に走査すれば, 電 荷の三次元分布が測定できる。

上記の厚さ方向分解能が保証されるためには，一点に存 在する空間電荷から生じ各方向へ伝搬した圧力波のうち, レンズで集められた波は全て同位相で（つまり同一の時刻 に）圧電素子へ到達しなくてはならない。しかし, 図 2 のよ うに, 圧力波が発生する位置から圧電素子までの経路中に, それぞれ相当の厚さを有するアルミニウム下部電極，水の 層, アルミニウムレンズがあり, 水とアルミニウムの音速 の差が大きいことから，これまでの球面レンズでは異なる 経路を通る圧力波の間に位相のずれが生じた。すなわち焦 点収差は大きく, 分解能は良くなかった。そこで, 今回, この問題を解決するために, 本測定装置の構造に適応した レンズの設計を行った。図 3 中でレンズの焦点 $\mathrm{P}$ で発生し た圧力波が, 圧電素子に到達するまでの下部電極, 水, レ ンズを通過する経路が異なっても, 圧力波が圧電素子に到 達する時間が等しくなるよう，それぞれの部分の音速を考

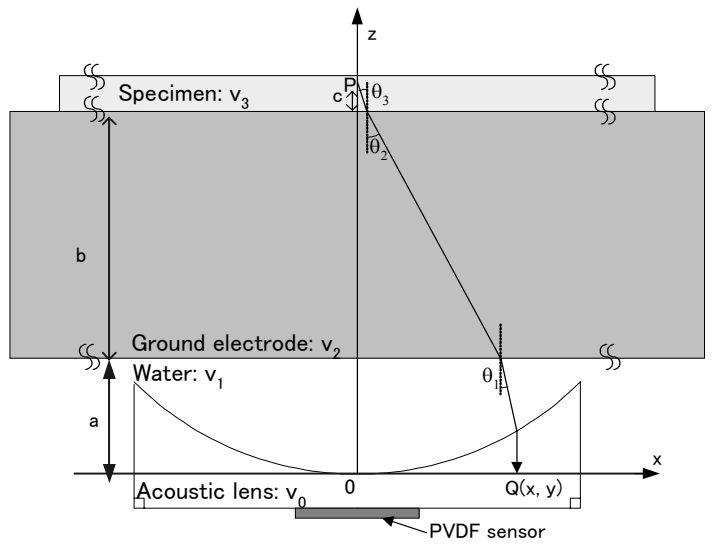

図 3 レンズの設計

Fig. 3. Design of lens.

慮して，レンズの凹部の形状を決定した。

レンズ面上の座標 $\mathrm{Q}(0,0)$ をレンズ中心の底の位置 $\mathrm{O}$ 点と し, 任意の位置 $\mathrm{Q}(x, y)$ でのレンズ面の高さを $z$ すると, $\mathrm{PO}$ 間と $\mathrm{PQ}$ 間での圧力波の伝達時閒が等しくなるためには, PO 間での伝達時間,

$$
t_{P O}=\frac{a}{v_{1}}+\frac{b}{v_{2}}+\frac{c}{v_{3}}
$$

と, PQ 間の伝達時間,

$$
t_{P Q}=\frac{z}{v_{0}}+\frac{a-z}{v_{1} \cos \theta_{1}}+\frac{b}{v_{2} \cos \theta_{2}}+\frac{c}{v_{3} \cos \theta_{3}}
$$

が $\mathrm{Q}(x, y)$ の全ての值に対して等しくなることが必要である。 ここで, $a, b$ は水と下部電極の厚さ, $c$ は焦点 $\mathrm{P}$ から下部 電極上面までの距離である。c の值は試料厚として数 $100 \mu \mathrm{m}$ を想定しているため $100 \mu \mathrm{m}$ とした。また $\theta_{1} ， \theta_{2}, \theta_{3}$ は該当 する界面での圧力波の入射あるいは出射角である。さらに $v_{0}, v_{1}, v_{2}, v_{3}$ は順にレンズ, 水, 下部電極, 試料中での音速 である。式中の $\theta_{1}, \theta_{2}, \theta_{3}$ の閒には圧力波の屈折の関係から, $\sin \theta_{1}: \sin \theta_{2}: \sin \theta_{3}=v_{1}: v_{2}: v_{3}$ すなわち,

$$
\begin{aligned}
& \theta_{1}=\sin ^{-1} \frac{v_{1} \sin \theta_{2}}{v_{2}} \\
& \theta_{3}=\sin ^{-1} \frac{v_{3} \sin \theta_{2}}{v_{2}}
\end{aligned}
$$

の関係が成り立っている。

(1), (2)式, 図 3 より,

$$
\begin{gathered}
z=\frac{\frac{a\left(1-\cos \theta_{1}\right)}{v_{1} \cos \theta_{1}}+\frac{b\left(1-\cos \theta_{2}\right)}{v_{2} \cos \theta_{2}}+\frac{c\left(1-\cos \theta_{3}\right)}{v_{3} \cos \theta_{3}}}{\frac{1}{v_{1} \cos \theta_{1}}-\frac{1}{v_{0}}} . \\
x=(a-z) \tan \theta_{1}+b \tan \theta_{2}+c \tan \theta_{3}
\end{gathered}
$$

という二つの関係式が得られる。上記の $(6),(7)$ 式に, $v_{0}=$ $v_{2}=6420 \mathrm{~m} / \mathrm{s}, \quad v_{1}=1500 \mathrm{~m} / \mathrm{s}, \quad v_{3}=2000 \mathrm{~m} / \mathrm{s}, \quad a=2 \mathrm{~mm}, \quad b=$ $5 \mathrm{~mm}, c=0.1 \mathrm{~mm}$ を代入した上で, 任意の $\theta_{3}$ に対するレ ンズの高さ $z$ を求めた。このようにして設計したレンズを 


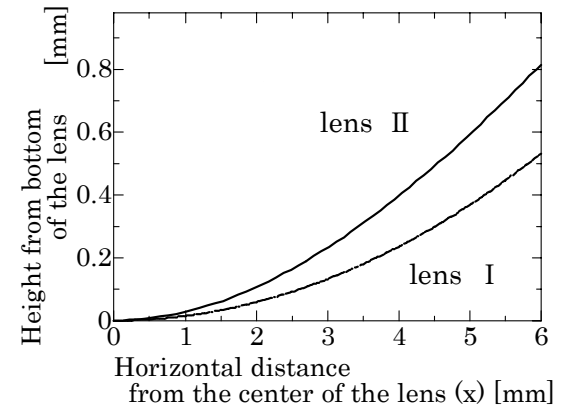

図 4 作成したレンズ II の形状

Fig. 4. The shape of lens II.

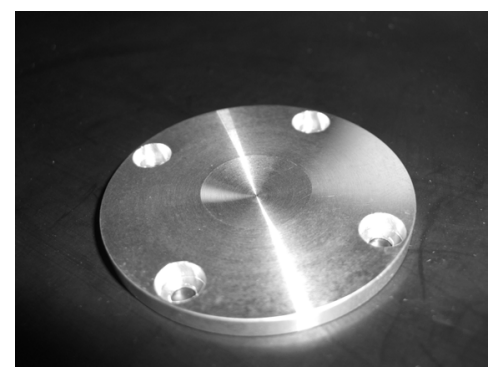

図 5 今回作成したアルミニウム製音響レンズ(lens II)

Fig. 5. The acoustic lens made by aluminum for this research. (lens II)

レンズII と呼び, 従来使用していたレンズをレンズ I と呼 ぶことにする。レンズ II の断面形状の計算值と, 従来のレ ンズ I の断面形状を図 4 に示す。さらに, 直径 $45 \mathrm{~mm}$, 厚 さ $3.5 \mathrm{~mm}$ のアルミニウム円板の上面中心部を数值制御旋 盤により切削して作成したレンズII を図 5 に示す。

\section{3. 新レンズの評価}

〈3·1〉 インパルス応答＼cjkstart最初にレンズ I, II を装着 した 3D-PEA 装置のインパルス応答を比較するために, 厚 さ $0.5 \mathrm{~mm}$ のポリメタクリル酸メチル樹脂（PMMA）に直 流電圧 $10 \mathrm{kV}$ を印加した場合に得られる信号を比較した。 ただし, 最も基本的な比較を行うために, 直径 $8 \mathrm{~mm}$ の上 部電極の中心の真下に音響レンズの中心をおいて測定を行 った。

直流電圧印加により上部，下部両電極面上に電荷が発生 するが，このうち下部電極面上電荷よりの信号を検出した ものを図 6 に示す。なお, この信号は, 装置のインパルス 応答であり，測定信号から電荷分布を得るためのデコンボ リューション操作 ${ }^{(4)}$ に際しての基準信号として用いられる。 この校正法では, 試料が均一な媒質である必要があり, 試 料が多層構造であったり，内部に導体を含むような場合に は電荷密度の值を正しく校正することはできないが，定性 的な評価は可能と思われる。なお, 装置のインパルス応答 の半值幅(ns) は, 測定試料中での圧力波の音速と掛け合わせ ることで距離に換算され，厚さ方向の位置分解能と定義さ れる。図 6 において, 新しいレンズ II を装着させた装置の
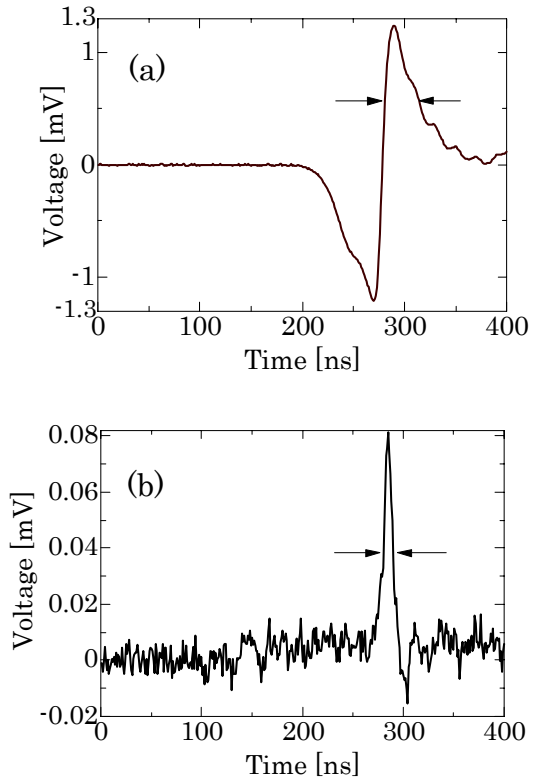

図 6 新旧レンズを用いた場合のインパルス応答の比較 :

(a) 旧レンズ I ，（b）新レンズ II

Fig. 6. Comparison of impulse responses between the new and old lenses; (a) old lens I, (b) new lens II .

インパルス応答(b)は, 古いレンズ I での応答(a)と比ベ半值 幅が非常に狭い。デコンボリューション処理後に換算した 厚さ方向の位置分解能は, 古いレンズ I で $30 \mu \mathrm{m}$ 程度であ るのに対して, 新しいレンズIIでは $16 \mu \mathrm{m}$ 程度となり，レ ンズ IIの方が分解能に優れている。また，レンズ IIをつけ た装置を用い, PMMA に直流電圧 $10 \mathrm{kV}$ を印加したときの 出力信号を図 7(a)に示す。さらに, この信号を図 6(b)に示 すインパルス応答を基準として校正した結果としての電荷 分布，さらにそれを 1 階および 2 階積分した結果としての 電界と電位の分布を, それぞれ図 7 (b), (c), (d)に示す。電 荷と電界の分布には乱れがあるものの試料両端の電位差は $10 \mathrm{kV}$ になっており, 印加電圧と良く一致している。

〈3·2〉 面方向分解能の評価 音響レンズによる結像 系では，焦点以外の場所で生じた信号は圧電素子上で位相 がランダムとなるため, 出力信号として検出されない。レ ンズ II はこの焦点領域, すなわち, 出力信号を生じる試料 の領域が狭いため必然的に検出信号は図 6(b)に示されるよ うに小さくなる。一方, レンズ I は焦点領域が広く, 解像 度が劣ることと引き換えに図 6(a)に示されるような比較的 大きな信号が得られる。そこで，以下の試料 A， B を用い， 上部電極の中心軸に沿って電荷分布の三次元測定を行い, 各レンズの信号検出領域を調べた。

（1）試料 A 製造過程で試料の片面にのみ, 表面から深 さ数 $10 \mu \mathrm{m}$ までの部分に亘って負に帯電した厚さ $0.3 \mathrm{~mm}$ のポリ塩化ビニル $(\mathrm{PVC})^{(3)}$ 板を幅 $1 \mathrm{~mm}$ の細い帯状に切 り, 同じ厚さの帯電していない PVC 板で左右より挟んだも の。

（2）試料 B 厚さ $100 \mu \mathrm{m}$ のポリエチレンテレフタレー 


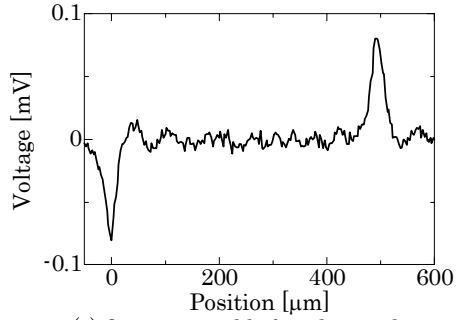

(a) Output signal before deconvolution

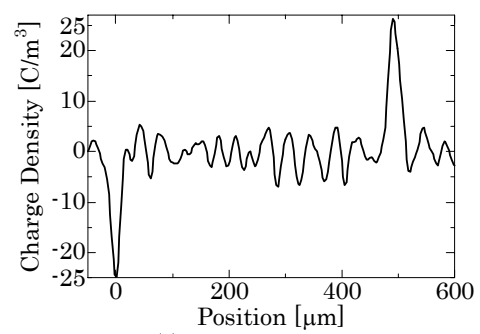

(b) Charge distribution

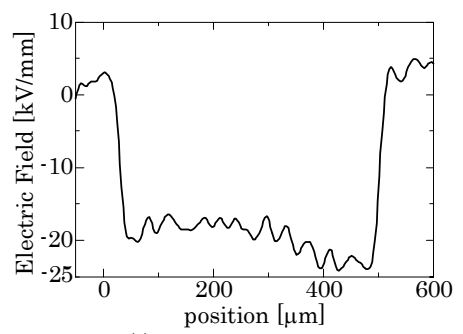

(c) Electric field distribution

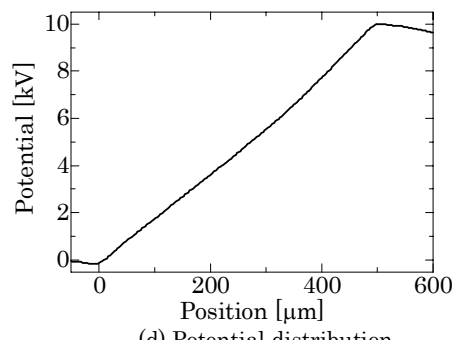

(d) Potential distribution

図 7 直流電圧 $+10 \mathrm{kV}$ が印加された厚さ $0.5 \mathrm{~mm}$ の

PMMA 板をレンズ【をつけた装置で測定

したときの信号波形

Fig. 7. Charge, electric field, and potential distributions in the PMMA board with a thickness of $0.5 \mathrm{~mm}$, measured by the PEA apparatus with the new lens II during the application of dc $10 \mathrm{kV}$.

ト $(\mathrm{PET})$ フィルムを二枚重ねたもの。PEA 装置の圧電素 子側の電極（下部電極）上におかれたフィルム上には，ア ルミニウムが幅 $2 \mathrm{~mm}$ 長さ約 $6 \mathrm{~cm}$ の長方形状に蒸着され ており，このフィルムの上に蒸着部の端が少しだけ露出す る形で，同一厚さのもう一枚の PET フィルムが重ねられ， 上部電極で押さえられている。この露出した蒸着部に直流 電圧+2.5 kV を印加した。帯電面を下部電極側にした場合と 上部電極側にした場合について試料 $\mathrm{A}$ の電荷を測定した例 を図 8(a)，(b)に示す。図 8(a1)，(b1)の横軸は上部電極の中 心軸を基準とした面方向の位置座標, 縦軸は試料内厚さ方

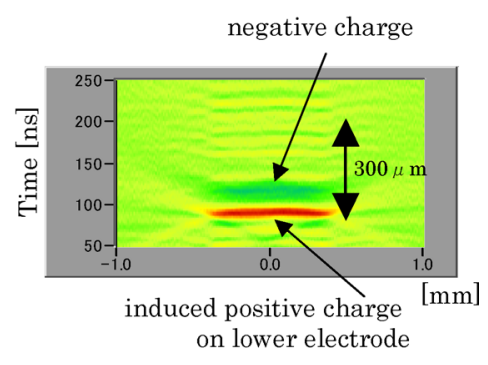

(a1) Cross sectional charge distribution

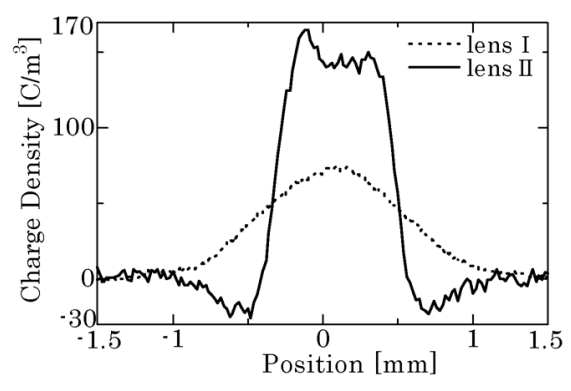

(a2) Charge distribution on the lower electrode surface

(a) Charged region on the lower electrode

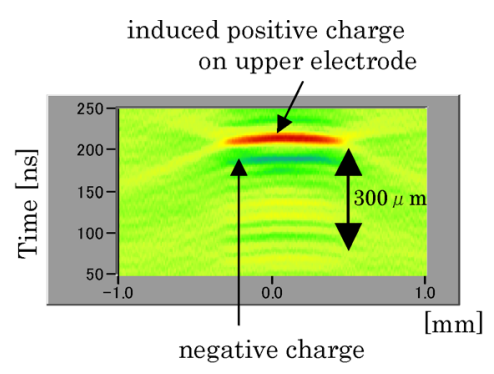

(b1) Cross sectional charge distribution

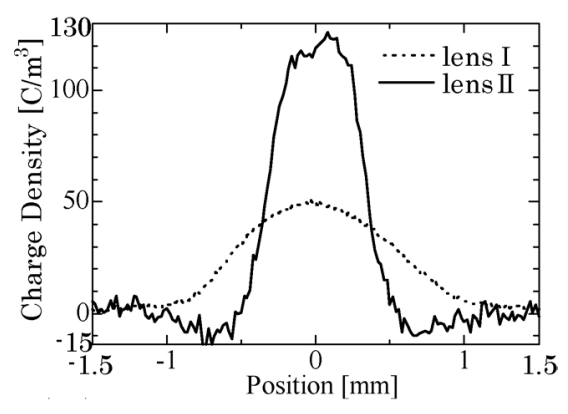

(b2) Charge distribution on the upper electrode surface

(b) Charged region on the upper electrode

図 8 表面の一部が帯電した PVC 試料 A の空間電荷 測定例 : 帯電面が下部電極上の例(a)と 上部電極上の例 $(\mathrm{b})$

Fig. 8. Charge distributions in PVC sample A with a surface charged region.

向の位置座標であるが ns で表示されている。1 ns は約 $2 \mu \mathrm{m}$ に相当する。すなわち，図 8(a1)，（b1)はいずれもレンズ II を装着させたシステムで得た二次元電荷分布像を表してい る。また, 図 8(a2), (b2)は PVC の帯電面に接している電 
極表面に現れる誘導電荷の面方向分布を表している。さら に，図 8(a2),（b2)において，点線はレンズ I による測定結 果，実線はレンズ II よる測定結果を示す。なお各測定点で レンズ I では約 860 回, レンズII では, 約 $1.3 \times 10^{4}$ 回の アベレージングを行った。

分解能が理想的に良い場合には，図 8(a2)，(b2)に示され る電荷分布は，PVC の帯電面と同一の幅を持った長方形に なるはずであるが，実際には歪んでいる。レンズ I により 測定された曲線がなだらかに変化するだけであるのに対し て，レンズ IIより測定された曲線は，帯電部分に対応す るほぼ一定值を示す領域が現れている。また, この一定值領 域は，帯電部分を上部電極側においた図 8(b2)よりも下部電 極側においた図 8(a2)の方が広い。一定值から減少する曲線 の傾斜も図 8(a2)の方が急である。これは，図 8(a1)，(b1) において各電極上の誘導電荷像の左右に見えるにじんだ部 分の長さが，図 8(a1)の方が小さいことと対応している。す なわち，圧電素子に近い下部電極に接して帯電部分をおい た方がより正確な電荷分布が測れることを示している。

ここで, 電荷分布が一定值から半值に下がるまでの距離 を面方向分解能と定義する。この定義に従えば，レンズ II を 用いて測定した場合の面方向分解能は図 8(a2)で約 $80 \mu \mathrm{m}$, 図 8(b2)で約 $120 \mu \mathrm{m}$ である。一方，レンズ I では，それぞ

induced negative charge positive charge on the on the upper electrode aluminum electrode

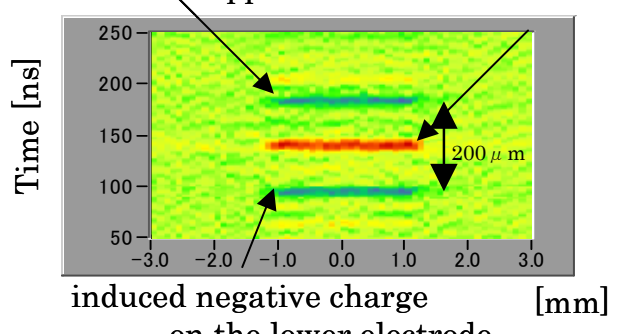

on the lower electrode

(a) Cross-sectional view

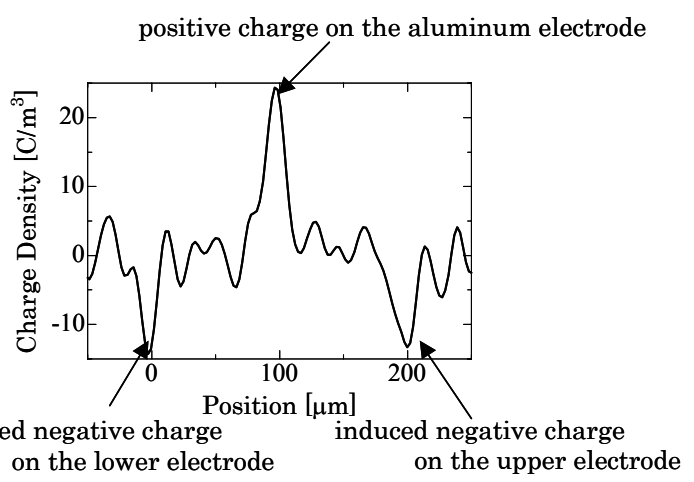

(b) Distribution along the thickness direction

図 9 蒸着アルミニウム電極に直流電圧 $+2.5 \mathrm{kV}$ を 印加したときの試料 B 内の空間電荷分布

Fig. 9. Charge distribution in sample B. A dc voltage of $+2.5 \mathrm{kV}$ was applied to the evaporated aluminum electrode.
れ分解能は約 $500 \mu \mathrm{m}$ であった。すなわち, レンズ II ではレ ンズ I と比べ面方向分解能が大幅に改良されている。

つぎに，試料 $\mathrm{B}$ の蒸着アルミニウム電極に直流電圧 +2.5 $\mathrm{kV}$ を印加したときにレンズ II をつけたシステムで測定され た電荷の二次元分布を図 $9(\mathrm{a})$ に, 上部電極の中心軸に沿っ た厚さ方向分布を図 $9(\mathrm{~b})$ に示す。アルミニウム電極上に正 電荷, 上部電極と下部電極に負の誘導電荷が生じているの が確認できる。また，位置分解能は図 9(a)より面方向に約 $150 \mu \mathrm{m}$, 図 9(b)より厚さ方向に約 $16 \mu \mathrm{m}$ と見積もられる。 試料 B では， 2 枚の PET フィルムの界面が存在すること， また信号強度が試料 A よりも小さいために分解能が悪い。

\section{4. むすび}

新たに非球面レンズを採用することにより，三次元空間 電荷分布測定装置の厚さ方向の位置分解能を $16 \mu \mathrm{m}$, 面方 向分解能を $100 \mu \mathrm{m}$ 程度と球面レンズを用いていたこれま での装置と比較し大きく向上させることが出来た。

(平成 17 年 4 月 5 日受付, 平成 17 年 10 月 4 日再受付)

\section{文献}

(1) T. Maeno : "Three-dimensional PEA Charge Measurement System", IEEE Trans. DEI., Vol.8, No.5, pp.845 - 848 (2001)

(2) K. Fukunaga, T. Maeno, and K. Okamoto : "Three-dimensional space charge observation of ion migration in a metal-base printed circuit board", IEEE Trans. DEI., Vol.10, No.3, pp.458 462 (2003)

(3) T. Maeno and K. Fukunaga : "High-resolution PEA Charge Distribution Measurement System ”, IEEE Trans. DEI., Vol.3, No.6, pp.754 - 757 (1996)

(4) T. Maeno: "Calibration of the Pulsed Electroacoustic Method for Measuring Space Charge Density”, T. IEE Japan., Vol.119-A, pp.1114 - 1119 (1999)

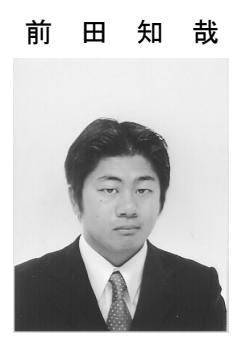

(学生員) 1979 年 8 月生まれ。 2003 年 3 月早 稲田大学理工学部電気電子情報工学科卒業。同 年 4 月早稲田大学大学院理工学研究科電気・情 報生命専攻修士課程入学，現在に至る。

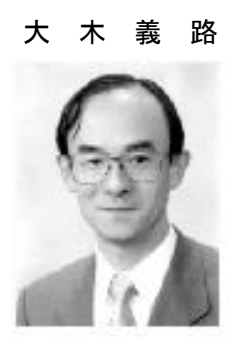

（正員） 1950 年 12 月生まれ。 1978 年 3 月早 稲田大学大学院博士課程修了。1976 年 4 月同 大学理工学部助手, 以降, 講師, 助教授を経て, 現在, 同教授。工学博士。有機および無機誘電 体材料の物性を研究。1989 年および 1997 年電 気学会論文賞, 1995 年矢崎学術賞, 2002 年 IEEE Foster 賞, 2004 年電気学会家田賞など 受賞, IEEE フェロー。 


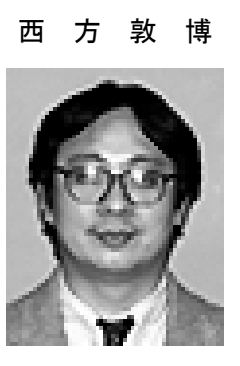

(非会員) 1961 年 1 月。 1989 年 3 月東京工業 大学大学院理工学研究科博士課程修了。1989 年 4 月郵政省通信総合研究所研究官, 同主任研 究官, 東京工業大学工学部電子物理工学科共通 助手を経て, 現在, 同大学教育工学開発センタ 一助教授。2004 年より情報通信研究機構短期 専攻研究員を兼任。工学博士。主として, 電磁 遮断, 電波吸収材料, 音源定位と応用等の研究 に従事。
前 野 恭 (正員) 1957 年 8 月。 1989 年 3 月武蔵工業 大学大学院工学研究科電気工学専攻博士課程 修了。現在, 情報通信研究機構電磁波計測部門 ライダーグループ所属。工学博士。主として誘 電体中の空間電荷分布, 電界分布の計測及びレ ーザー応用研究に従事。1999 年より武蔵工業 大学機械システム工学科客員助教授。1990 年 電気学会論文賞, 1997 年静電気学会進歩賞受 賞。 